\title{
Annotatie Kort
}

\section{Geert Wilders veroordeeld wegens groepsbelediging en aanzetten tot discriminatie}

\author{
Marloes van Noorloos
}

\section{Rb. Den Haag 9 december 2016, ECLI:NL:RBDHA:2016:15014}

$\mathrm{Na}$ een enerverend proces kwam de Rechtbank Den Haag op 9 december 2016 met het langverwachte oordeel in de zaak-Wilders II. De vrijspraak van Wilders door de Rechtbank Amsterdam in 2011 (Rechtbank Amsterdam 23 juni 2011, ECLI:NL:RBAMS:2011:BQ9001, NJ 2012, 370 m.nt. Mevis) suggereerde bij sommigen dat de uitingsvrijheid van de politicus onbeperkt was. In het arrest-Felter (HR 16 december 2014, ECLI:NL:HR:2014:3583, NJ 2015, 108 m.nt. Rozemond), waarin de Hoge Raad de vrijspraak casseerde van een lokale politicus die antihomo-uitspraken deed, werd duidelijk dat dat in elk geval niet het geval is. Twee dagen na dat arrest besloot het Openbaar Ministerie tot vervolging van Wilders voor zijn uitspraak op de uitslagenavond van de gemeenteraadsverkiezingen op 19 maart 2014 ('Willen jullie in deze stad en in Nederland meer of minder Marokkanen? / Dan gaan we dat regelen.'). Ook is Wilders in deze zaak vervolgd voor zijn uitspraak van een week eerder, tijdens een bezoek aan de markt in het Haagse stadsdeel Loosduinen ('...een stad met minder lasten en als het even kan ook wat minder Marokkanen'). Voor de 'minder Marokkanen'-uitspraak veroordeelde de rechtbank hem wegens belediging van een groep mensen wegens hun ras (art. 137c Sr) en aanzetten tot discriminatie van mensen wegens hun ras (art. 137d Sr). Wilders werd vrijgesproken van aanzetten tot haat. Met betrekking tot zijn uitspraak op de markt volgde vrijspraak op alle punten.

Gezien de publieke commotie rondom deze zaak is het niet gek dat de rechtbank de uitspraak aftrapt met een beschouwing over de vrijheid van meningsuiting en de vraag of er sprake is van een 'politiek proces'. Toch is de stelling dat er bij een strafvervolging van een politicus voor diens uitlatingen geen sprake is van een beperking van de uitingsvrijheid, omdat die uitingen 'van meet af aan niet werden beschermd door de vrijheid van meningsuiting', moeilijk te begrijpen. Een inperking van de vrijheid van meningsuiting blijft het nog steeds, alleen kunnen daar soms goede redenen voor zijn. Wanneer die goede redenen er zijn, dat is de vraag waar het om draait (en waar in de rest van het vonnis wel op in wordt gegaan).

Anders dan in de zaak-Wilders I richtte de PVV-leider zich met zijn uitspraken nu expliciet op 'Marokkanen'. Het begrip 'ras' in de uitingsdelicten heeft een brede eigen betekenis die gelijk is aan die in het Rassendiscriminiatieverdrag, waaronder ook huidskleur, afkomst en nationale of etnische afstamming vallen (HR 29 maart 2016, ECLI:NL:HR:2016:510 m.nt. Keijzer en ECLI:NL:HR:2016:511; HR 15 juni 1976, NJ 1976, 551 m.nt. Van Veen). Volgens de verdediging zagen de 
uitspraken echter niet op 'ras' als bedoeld in artikel 137c en d Sr, omdat de politicus met 'Marokkanen' niet op een gezamenlijke afkomst zou doelen, maar op hun huidige Marokkaanse nationaliteit die zij (naast de Nederlandse nationaliteit) bezitten. Daar maakt de rechtbank terecht korte metten mee: dat de leden van de Marokkaanse bevolkingsgroep in ons land toevallig ook de Marokkaanse nationaliteit hebben (waarvan men in de praktijk immers geen afstand kan doen) doet niet af aan het feit dat ze gezien kunnen worden als een groep die zich onderscheidt door hun gemeenschappelijke afkomst.

De rechtbank past vervolgens in het kader van de groepsbelediging (art. 137c) het toetsingskader toe zoals dat in de jurisprudentie is ontwikkeld voor de interpretatie van dat delict: (a) is de uitlating op zichzelf beledigend, (b) maakt de context dat anders en (c) zo ja, is de uitlating dan niet alsnog (binnen die context) onnodig grievend? Opvallend is dat de zaak hier al wordt beslist op het tweede punt: volgens de rechtbank leverde Wilders geen bijdrage aan het publieke debat, onder meer omdat hij bewust heeft gekozen voor een zo groot mogelijke impact en een eenzijdige geregisseerde interactie met de zaal aanging in plaats van in debat ging. Daarom komt de rechtbank aan de derde stap niet toe.

Ook de vrijspraak voor aanzetten tot haat is opvallend: volgens de rechtbank is er slechts sprake van krachtige retoriek en niet van het ophitsen of oproepen van mensen om iets te doen. Dat er in het taalgebruik zo'n 'krachtversterkend element' moet zitten vond ook de rechtbank in de Wilders I-zaak en dat criterium is op zichzelf niet zo vreemd. Dat de 'minder Marokkanen'-uitspraak in combinatie met de daarop volgende interactie met het publiek niet zodanig ophitsend was, had echter wel wat meer uitleg behoefd - zeker omdat het opruiend karakter van de uitspraken vervolgens wel wordt genoemd bij de veroordeling voor aanzetten tot discriminatie. Zowel in de vrijspraak voor aanzetten tot haat en in de veroordeling voor aanzetten tot discriminatie ontbreekt een uitgebreide motivering aan de hand van het toetsingskader zoals dat bij groepsbelediging wel wordt gebruikt.

Dit alles resulteert in een veroordeling zonder oplegging van straf. De constatering dat Wilders 'voldoende gestraft' is, werpt daarbij wel de vraag op of het ondergaan van een dergelijk proces daadwerkelijk zo'n straf is voor de politicus. Toch is het in een proces als dit goed te begrijpen dat de rechtbank de focus niet legt op de sanctie, maar op het belang van bevestiging van de norm dat ook een politicus zich niet schuldig mag maken aan groepsbelediging en aanzetten tot discriminatie. 


\title{
Dynamische verkeerscontrole in strijd met verbod etnisch profi- leren
}

\author{
Peter Rodrigues
}

\section{Rb. Amsterdam 16 januari 2017, ECLI:NL:RBAMS:2017:370}

De politierechter stelt vast dat uit het proces-verbaal van bevindingen van de politie blijkt dat verbalisanten twee Marokkaans uitziende jongemannen zien rijden in een Volkswagen Golf en dat zij daarom besluiten de bestuurder en bijrijder van deze auto aan een verkeerscontrole te onderwerpen. Nu slechts dit de reden is geweest die ten grondslag lag aan de verkeerscontrole, doet zich de situatie voor zoals door de Hoge Raad in het arrest van 1 november 2016 (ECLI:NL:HR: 2016:2454) beschreven, te weten een selectie van het voertuig hoofdzakelijk gebaseerd op de etnische kenmerken van de inzittenden ervan. De uitoefening van de controlebevoegdheid is daarmee onrechtmatig. De politierechter acht daarom uitsluiting van het verkregen bewijsmateriaal aangewezen, zodat verdachte, vanwege gebrek aan voldoende bewijs, van het ten laste gelegde dient te worden vrijgesproken.

Deze uitspraak is gebaseerd op HR 1 november 2016 waarin twee belangrijke uitgangspunten zijn geformuleerd. Allereerst is overwogen dat uitoefening van controlebevoegdheden als bedoeld in artikel 160 lid 1 en 4 Wegenverkeerswet verband dient te houden met de naleving van de bij of krachtens die wet gegeven voorschriften. Dit betreft de zogenoemde 'dynamische verkeerscontrole' waarbij de bestuurder van een voertuig op grond van bepaalde kenmerken wordt staande gehouden. Deze methode wordt ook wel de 'patseraanpak' genoemd. Die uitoefening is in beginsel rechtmatig, ook indien die daarnaast het verrichten van opsporingshandelingen mogelijk maakt waarop deze bepalingen niet zien. Die omstandigheid brengt immers nog niet mee dat de controlebevoegdheid uitsluitend is gebruikt voor een ander doel dan waarvoor deze is verleend. Eerder had het Hof Amsterdam geoordeeld dat hier sprake was van misbruik van bevoegdheid.

Vervolgens is het aan de rechter te oordelen of de politie bij de uitoefening van haar bevoegdheden de te controleren persoon of personen heeft geselecteerd op een wijze die onverenigbaar is met het uitgangspunt dat personen niet worden gediscrimineerd op grond van onder meer hun ras of hun godsdienst of levensovertuiging. Indien de rechter van oordeel is dat bij die selectie een in dit opzicht niet gerechtvaardigd onderscheid is gemaakt, zal hij moeten bepalen welk rechtsgevolg in de gegeven omstandigheden moet worden verbonden aan de onrechtmatigheid van de uitoefening van de controlebevoegdheid, rekening houdend met factoren als de ernst van het verzuim en het nadeel dat daardoor wordt veroorzaakt. Een dergelijke bevinding kan in het bijzonder in beeld komen indien de selectie van het voor een verkeerscontrole in aanmerking komend voertuig uitsluitend of in overwegende mate is gebaseerd op etnische of religieuze kenmerken van de bestuurder of andere inzittenden van dat voertuig. 
Met de uitspraak volgt de kantonrechter het arrest van de Hoge Raad van 1 november 2016. Indien uit het proces-verbaal blijkt dat de etniciteit uitsluitend of in overwegende mate de reden voor het proactief toezicht is geweest, is de staandehouding onrechtmatig (analoog aan EHRM 13 december 2005, Timishev t. Rusland, 55762/00 en 55974/00). Dit is een goede rechtsontwikkeling ter voorkoming dat bij proactief politieoptreden ongerechtvaardigd onderscheid naar etniciteit wordt gemaakt (zie Rodrigues en Van der Woude, 'Proactieve politiecontrole en onderscheid naar etniciteit of nationaliteit', NJB 2016, afl. 32, p. 2294-2302). Dat neemt niet weg dat bij het arrest van de Hoge Raad ook kanttekeningen kunnen worden geplaatst. Aangezien de staandehouding in die zaak was gebaseerd op de omstandigheid dat het autoverhuurbedrijf vaker aan criminelen verhuurde, de dure auto zich in de verkeerde 'witte' wijk bevond en dat de chauffeur Hindoestaanse en de bijrijder Oost-Europese etnische kenmerken vertoonden. Dit werd door de verbalisanten 'een opvallende combinatie gevonden'. Het is mij niet duidelijk wat de toegevoegde waarde van deze etnische constatering is en waarom dit een indicatie zou zijn - in combinatie of afzonderlijk - van mogelijk 'fout' gedrag. Het is jammer dat de Hoge Raad de deur op een kier zet voor etnisch profileren, het mag immers indien er voldoende andere omstandigheden worden aangevoerd. In het

Rapport Boeven vangen (W. Landman en L. Kleijer-Kool, Amsterdam: Reed Business 2016, p. 233-235) wordt opgemerkt dat bij het professioneel profileren etniciteit geen indicator hoeft te zijn en het alleen maar leidt tot ongewenste neveneffecten. Ik sluit mij daar graag bij aan. 